\title{
Shelf Based Out-of-Stocks in the Context of Employee Density
}

\author{
Aleksandar Grubor, Nikola Milicevic, Nenad Djokic, Nemanja Berber
}

\author{
University of Novi Sad \\ Segedinski put 9-11, 24000 Subotica, The Republic of Serbia \\ E-mail.agrubor@ef.uns.ac.rs, milicevic.nikola@ef.uns.ac.rs,djokicn@ef.uns.ac.rs, berber@ef.uns.ac.rs
}

cross $^{\text {ref }}$ http://dx.doi.org/10.5755/j01.ee.28.4.16194

\begin{abstract}
The purpose of this paper is to investigate the effect of employee density on shelf based out-of-stocks, i.e. situations when products are physically present at stores, but not on the marked sale positions. In addition, for the first time, these relations were analyzed among different retail formats. By using POS estimation method, shelf based out-of-stock rates were measured for 80 different FMCG products in 97 retail stores. For analyzing the impact of employee density on the average shelf based OOS rate in modern and traditional retail formats, curvilinear hierarchical regression and moderation analyses were used. The results showed that the relation between employee density and shelf based out-of-sock varied among different formats. While it was not significant in convenience stores, in modern formats it was quadratic (stores with too many or too few employees per square meter were related to higher levels of shelf based OOS). The obtained results suggest that store managers should be aware of the effects of employee organization on product availability. The attention was also dedicated to potential problems and managerial implications concerning the employees' number in retail stores, regarding traditional and modern trading formats.
\end{abstract}

Keywords: Retail, Product Availability, Shelf Based Out-Of-Stocks, Employee Density.

\section{Introduction}

In the conditions of escalating struggle for a shrinking share of consumers' wallets (Grewal et al., 2009), retailers must pay special attention to increasing the level of their services. In retail sector, it is most often related to stock levels, that is, on-shelf availability (Trautrims et al., 2009). Therefore, by increasing stock levels, the level of customer service, manifested through product availability, increases as well.

From the aspect of retail service, product availability represents one of the customer-perceived indicators of instore logistics performance which is positively associated with customer satisfaction and loyalty (Bouzaabia et al., 2013). According to Cottet et al. (2006, p. 224), it is the only store's characteristic that has an impact on the utilitarian value: the more easily available the products, the higher the store's utilitarian value and the greater customer satisfaction. Taking into account that satisfied customer represents the basis for business maintenance (Blesic et al., 2014), achieving higher levels of product availability should be considered as one of the major tasks for both retailers and their suppliers (manufacturers).

Ehrenthal et al. (2014) analyzed the importance of onshelf availability in the context of value creation process which involves manufacturer, retailer and customer. Value co-creation occurs only when the resources of each actor integrate for a certain point in time and space. By making the manufacturer's items available to the customer, retailer, as primer integrator, creates preconditions for successful exchange of service. Otherwise, in the case of out-of-stock (OOS), when, for some contiguous time, an item is not available for sale as intended (Gruen \& Corsten, 2007, p. 1), the value realization process will be jeopardized. Besides the changes in manufacturer and retailer value proposition, if customer decides to cancel the purchase in OOS situation, value will not be realized by any actor.

In today's consumer-driven business conditions, the out-of-stock represents serious issue for all market participants. In addition to costs, in stock-out situations, customers may be confronted with the loss of their time and energy (Roland Berger Consultants, 2003) which is particularly worrying bearing in mind that they place an emphasis on leisure time as well (Wlodarczyk, 2013). Despite the fact that product availability is one of the 3 top reasons for choosing a retail store, on the average, during every visit, one of 12 products from the shopping list and one of 10 or fewer promoted products are not to be found on the shelf (FMI/GMA Trading Partner Alliance, 2014).

The problem of out-of-stock can have short-term and long-term consequence for retailers (Kim \& Lennon, 2011). Short-term effects are primarily reflected in loss of sales. It occurs when customer cancels the purchase, buys the product in another store, or opts for smaller and/or cheaper substitutes (Gruen et al., 2002). At the global level, according to Gruen \& Corsten (2007), annual loss of sales, directly caused by out-of-stocks, amounts to $4 \%$. On the other hand, long-term effects of stock-outs may include loss of market share, customer dissatisfaction, loss of patronage, and negative word-of-mouth (Kim \& Lennon, 2011). Outof-stock situations may cause customers to stop or reduce their orders, spend less and diminish subsequent conversion rate (Andersen et al., 2006), which eventually can lead to the decrease of their loyalty. According to the research of ECR AP (2012), for the greatest percentage of retailers (40\%) lower customer satisfaction is the most significant consequence of poor on-shelf availability, whereas for $23 \%$ of them it is loss of sales. 
Similar to retailers, manufacturers can also be faced with loss of sales, when a customer in the out-of-stock situation gives up the purchase or substitutes the brand. On average, these losses cost manufacturers \$23 million for every $\$ 1$ billion in sales (Gruen \& Corsten, 2007). In addition to sale losses, another significant problem may be the decrease of brand loyalty. However, unlike retailers, who pay more attention to the indirect effects of out-of-stocks, the majority of manufacturers regard loss of sales as the most significant OOS consequence (ECR AP, 2012).

The out-of-stock problem may have a negative impact on the operational efficiency and effectiveness of business processes at both supply chain members. Whereas at retailer it may lead to poor in-store execution, manufacturers may incur lowered effectiveness of marketing and planning processes, such as forecasting, production scheduling, promotions and new product development (Ehrenthal et al., 2014). Also, one should not neglect the disrupted relations between trading actors due to exchange of imprecise and/or incorrect information, or the addition costs that may occur when taking corrective actions.

As regards the importance of product availability for all the supply chain members, and also all the negative consequences of stock-outs, this theme has been investigated from several aspects. In many studies (Gruen et al., 2002; Roland Berger Consultants, 2003; Corsten \& Gruen, 2003; Aastrup \& Kotzab, 2010; Ehrenthal \& Stolzle, 2013) attention was dedicated to identifying main root causes of OOS situations. According to their results, a large percentage of out-of-stock causes appear at the store level, emphasizing the importance of employee factor. Store employees are especially responsible for shelf based OOS situations, when products are in the store, but not on the shelves. Their unintentional or deliberate mistakes in realization of backroom-to-shelf operations are usually followed by stock-outs. Poor organization of in-store processes, low motivation and inadequate number of store employees are just some of the reasons for low on-shelf availability. However, only few authors (Angerer, 2005; DeHoratius \& Ton, 2009; Ton \& Raman, 2010) examined relations between employees' characteristics and out-ofstocks. Therefore, the scientific problem of this article is the relation between shelf based out-of-stocks and employee density. Moreover, bearing in mind the differences in organizational processes, retail formats (traditional and modern) were used as a moderator in this relation.

The subject of this article includes the average shelf based OOS rates and employee density levels (number of employees per square meter) for 97 retail stores, grouped into modern and traditional formats.

The aim of this research is to investigate the effect of employee density on shelf based out-of-stocks, depending on retail formats.

Research methods include the scientific literature analysis, POS estimation method (for calculating shelf based OOS rates) and statistical techniques (curvilinear hierarchical regression and moderation analysis).

Novelty is manifested through the obtained results which point to potential problems concerning the employees' number in retail stores, and thus provide a significant information resource for store managers; in addition, this article contributes to the analysis of on-shelf availability, especially bearing in mind that relations between employee density and shelf based out-of-stocks were investigated among modern and traditional formats for the first time.

\section{Theoretical Background}

\section{Store and Shelf Based out-of-Stocks}

With the downstream movement of products in the supply chain, from the manufacturer to the retailer, availability, and consequently the level of service, declines as well. According to Roland Berger Consultants (2003) it is the lowest in the final meters, from the backroom to the shelf. While the average out-of-stock worldwide rate is 8.3 $\%$ (Gruen et al., 2002), in Europe its value is between $7 \%$ and $10 \%$ (Roland Berger Consultants, 2003). Aastrup \& Kotzab (2010) pointed in their study that despite more than 40 years of research (Progressive Grocer, 1968), OOS rates are stagnant at the given level of $7 \%$ to $8 \%$.

However, the results of the research of Ehrenthal \& Stolzle (2013) significantly differ from the previous ones concerning the out-of-stock levels. In their study, OOS rates were even lower than $1 \%$. Still, according to these authors $(2013$, p. 65) obtained results "indicate that the causes of stock-outs are likely to be retailer and storespecific". In several studies (Fernie \& Grant, 2008; Aastrup \& Kotzab, 2009; Milicevic \& Grubor, 2015) outof-stock levels were analyzed in the context of store characteristics, including its size and format. Their results have shown that larger retail stores are characterized by lower OOS levels. Reason for this lies not only in better space allocation possibilities (Aastrup \& Kotzab, 2009) but in better store personnel management as well. Following Grubor \& Milicevic (2015), opposite to smaller stores, in modern retail formats (supermarkets and hypermarkets) instore processes are organized in compliance with category management concept.

That the highest percentage of out-of-stocks occurs in retail stores, i.e. that the retailer is responsible for their causes in most cases, is confirmed by the results of several studies (Andersen Consulting, 1996; Gruen et al., 2002; Roland Berger Consultants, 2003; Corsten \& Gruen, 2003; Gruen \& Corsten, 2007; McKinnon et al., 2007; Aastrup \& Kotzab, 2009; Ehrenthal \& Stolzle, 2013). The OOS event can occur when product is not physically present at the store, usually as a result of forecasting or ordering inaccuracy, delivery processes and upstream supply problems (Gruen \& Corsten, 2007). This kind of stock-out, when the store is completely out of inventory, Gruen \& Corsten (2007) referred as store based out-of-stock.

However, it often happens that product is physically somewhere in the store, but not at the expected labelled place (store shelf) so that customers cannot find or buy it. These products may be miss-shelved or left in the storage areas (DeHoratius \& Ton, 2009). In both cases, shelf based out-of-stocks occur (Gruen \& Corsten, 2007).

According to Andersen Consulting (1996), 8 \% of outof-stocks is related to the products mentioned above. On the other hand, the results of other studies point that much higher percent of stock-outs refers to products which are present in the store, but not on the shelf. While Gruen et al. 
(2002) found that $25 \%$ of out-of-stocks worldwide and 38 $\%$ of out-of-stocks in Europe are attributed to these products, according to DeHoratius \& Ton (2009), misplaced products can share as much as $60 \%$ of OOS.

Shelf based out-of-stocks are especially frustrating for customers. Two surveys at stores of a large US retailer have shown that one out of six customers who asked a salesperson for help finding something had experienced this kind of stock-out (Ton, 2012, p. 128). For retailers, in addition to sales losses (Ton \& Raman, 2010), this problem can cause the distortion of POS data which leads to poor inventory and promotion planning (Ton, 2012). As products, in these situations, are already present somewhere in the store, i.e. their inventory records are positive, retailers may mistakenly perceive that their demand has been reduced or doesn't exist at all. Consequently, it further reflects on retailer's forecasting and ordering processes as well.

Main root cause areas for shelf based out-of-stocks refer to shelf replenishment and planogram compliance operations (Gruen \& Corsten, 2007). Congested backrooms, insufficient or busy store employees, shrinkage, placement not compliant to planogram, secondary placement, insufficient shelf space, infrequent late or no shelf filling are just some of issues that cause these stock-outs (Gruen et al., 2002; Ehrenthal \& Stolzle, 2013).

\section{Employees and Out-of-Stocks}

Bearing in mind that store execution processes rely on store employees and the way that the store and the employees are managed (Trautrims, 2011), these factors also affect shelf based out-of-stocks. In addition to poor process design, DeHoratius \& Ton (2009) emphasized two more sources of poor execution: an operating environment that makes it challenging for employees to conform to prescribed processes, and employee errors. According to these authors, even when processes are well-designed, in an operating environment where compliance to designed processes is not monitored or rewarded, employees may choose not to carry out their duties properly. However, besides deliberate avoidance of carrying out store processes, employees may make unintentional errors which can also lead to shelf based stock-outs. They may shelve a product in the wrong display area on the selling floor, shelve extra units of a product in the wrong location in the storage area, forget to shelve the new products and leave them in the receiving area, place all the units of a new product in storage areas rather than shelving some of them, and forget to replenish the selling floor when the units there are sold (Ton \& Raman, 2010). While in the first two cases products are misplaced on the selling floor or in the storage areas, in the last three they are phantom, i.e. they are physically present in the store, but only in storage areas where customers cannot find them (Ton \& Raman 2006). Considering mentioned errors and their effects, product availability was analyzed in several studies in the context of store employees.

In the research conducted by ECR UK (2007), store employees from nine stores across three retailers in UK were interviewed regarding the poor product availability. $26 \%$ of interviewed employees think that they have a lot of work and $23 \%$ of them did not receive any communication on onshelf availability (OSA). In addition, $61 \%$ of interviewed employees did not have formal OSA training.

Using the data of a single retailer, Ton \& Raman (2006) investigated the effect of several factors on phantom products at store level. Therefore, besides significant negative relationship between the percentage of phantom products and the amount of training at the store, these authors have found that stores with higher employee workload have higher percentage of these products. By analyzing the data of the same retailer, Ton (2008) has also shown that increased staffing levels are associated with lower percentage of phantom products and poorly selling products that were supposed to be returned to the distribution centre but remained in the stores.

Starting from the economic theory of work which refers to quadratic relationship between work effort and efficiency (Fairris, 2004; Angerer (2005) has analyzed outof-stock levels from the aspect of personnel density, assuming that the number of store employees can have a quadratic impact on store operations and thus on product availability. Thereby, in addition to understaffed, he paid attention to problems related to overstaffed stores as well. While, in the former, employees are overworked, in the latter, boredom, low motivation and coordination issues may occur. Consequently, he investigated the relation between the average OOS rates (on a store level) and the number of employees per $\mathrm{m} 2$ sales area also with ANOVA method. By using the sample of 84 FMCG products in 10 stores of a major European retailer, he partially confirmed that stores with too low or too high personnel density have more OOSs.

Following Angerer (2005), the subject of our research was also the quadratic relation between employee density and OOS. However, bearing in mind that store employees are most responsible for situations when products are somewhere in the store, but not on the marked points of sale, we have focused on shelf based out-of-stock events. In addition, taking into account the earlier mentioned differences in OOS levels between retail formats (Grubor \& Milicevic, 2015), this variable has been used as a moderator. Thus, we tested the following hypothesis:

$H_{1}$ : Retail formats moderate the effect of employee density on shelf based out-of-stocks.

Afterwards, we have investigated this effect among traditional and modern formats. Opposite to smaller stores that have poor organization and little specialization, where employees perform multiple activities, in modern retail formats replenishment and merchandizing activities are managed at the category level (Levy \& Weitz, 2012; Grubor \& Milicevic, 2015). Thereby, an inadequate number of store employees in such organized systems may cause in-store problems and consequently shelf based outof-stocks. Following this, we developed the hypothesis:

$\mathrm{H}_{2}$ : Employee density has quadratic impact on shelf based out-of-stocks within modern format group.

The hypothesis $\mathrm{H}_{2}$ implies that modern format stores with too many or too few employees per square $\mathrm{m}$ sales area are related to higher levels of shelf based OOS. 


\section{Research Methodology}

\section{Sample}

Following reviewed literature, we examined relations between employee density and shelf-based out-of-stocks within traditional and modern retail formats. For this analysis we have used conceptual model presented in Figure 1.

Our sample includes 97 retail stores of a retailer that ranges among three top retailers on the Western Balkans and which according to its annual revenue is placed among 100 biggest companies in Southeast Europe (Andreevska et al., 2014). In terms of the size (Lovreta et al., 2009) and retailer's internal organizational concept, all stores are divided into traditional and modern formats. Thereby, we have 49 smaller retail stores with sales area lower than 400 square meters and 48 modern formats, including supermarkets and hypermarkets.

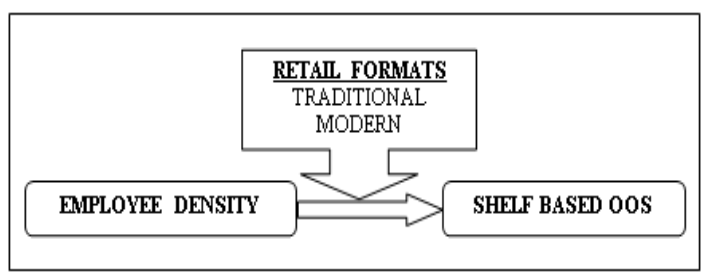

Figure 1. Conceptual model

Source: Authors

In cooperation with the retailer's supply chain director, we selected 80 different FMCG products from each retail store. They were taken from several categories: basic foodstuff (edible oils and fats, sugar and products made from sugar, cereal-based products and flour), spices and aromas, sweets, salty snacks, drinks, coffee and tea, personal hygiene care products and household care products.

\section{Method}

For calculating out-of-stock levels, we have used POS sales estimation method (Hausruckinger, 2005; Gruen \& Corsten, 2007). In this regard, the OOS rate for item $i$ in store $s$ is computed as the ratio of lost (LS) and expected sales (ES) in units over a given period of time, where the lost sale is the difference between the average and real sale:

$$
O O S_{i s}=\frac{L S_{i S}}{E S_{i s}} * 100
$$

Because Hausruckinger's approach for estimating expected sales boundaries can be problematic for items with high sales volatility, as Grubor and Milicevic (2015), we also relied on features proposed by Papakiriakopoulos \& Doukidis (2011).

For each product, besides ordinary OOS rate, by using formula (1) we have calculated store based OOS rate (when product is not physically present in the store) as well. Their difference represents the level of shelf based out-of-stocks:

$$
\text { Shelf based } O O S_{i s}=O O S_{i s}-\text { Store based } O O S_{i s}
$$

After computing shelf based OOS rates for all products, we calculated its mean level for each of the 97 stores (Shelf based OOS $_{\text {store }}$ ). Also on a store level, employee density was figured as the number of employees per square meter sales area (Angerer, 2005). For the purpose of this research, we used data obtained from retailer's ERP information platform connected with stores' POS terminals. Daily sales and inventory data for all sampled products as well as necessary store characteristics (number of employees and size of sales area), have been collected in 2014.

Bearing in mind that stores with too many or too few employees are more susceptible to OOS situations (Angerer, 2005), for investigating relation between employee density and shelf based out-of-stock on a store level, we used quadratic regression analysis with retail format as moderator. Therefore, our model consisted of dependent variable (Shelf based OOS $_{\text {store), one continuous }}$ predictor (employee density), its quadratic term, one categorical moderator (retail format) and their interactions.

Following Frazier et al. (2004), before structuring the equation, we coded categorical variable and centred continuous predictor. For the first operation, we applied dummy variable coding with traditional format as the reference group (code variable $C$ had a value 0 in traditional format group and a value 1 in modern format group). In order to reduce multicollinearity problems, we centred continuous predictor (employee density) and calculated its squared values (Cohen et al., 2003; Whisman $\&$ McClelland, 2005). In addition to these changes, we entered interaction terms, presented as products of centred predictors and coded categorical variable (West et al., 1996). After all modifications, our regression model is structured as follows:

Shelf based OOS $S_{\text {store }}=b_{0}+b_{1} E D_{c}+b_{2} E D_{c}^{2}+b_{3} C+$ $b_{4}\left(E D_{c} \times C\right)+b_{5}\left(E D_{c}{ }^{2} \times C\right)$

Hence, our full regression model included five independent variables: centred employee densities $\left(\mathrm{ED}_{\mathrm{c}}\right)$, centred employee densities squared $\left(\mathrm{ED}_{\mathrm{c}}{ }^{2}\right)$, coded variable (C) and two product terms $\left(\mathrm{ED}_{\mathrm{c}} \mathrm{xC}\right.$ and $\left.\mathrm{ED}_{\mathrm{c}}{ }^{2} \mathrm{xC}\right)$. For detecting auto-correlation we used Durbin-Watson test and for checking multicollinearity we relied on variance inflation factors.

\section{Research Findings}

Descriptive statistics for different types of out-ofstocks and employee density is presented in Table 1. The mean out-of-stock rate on a store level amounts $1,93 \%$. On average, more than $30 \%$ of it consists of phantom or products that are misplaced somewhere in the store. 
Table 1

Descriptive Statistics

\begin{tabular}{lccccccccc}
\hline \multirow{2}{*}{ Formats } & \multirow{2}{*}{$\mathbf{N}$} & \multicolumn{2}{c}{ Out-of-stock } & \multicolumn{2}{c}{ Store based OOS } & \multicolumn{2}{c}{ Shelf based OOS } & \multicolumn{2}{c}{ Employee density } \\
\cline { 3 - 9 } & & Mean & S.E. & Mean & S.E. & Mean & S.E. & Mean & S.E. \\
\hline Traditional & 49 & 0.0206 & 0.0019 & 0.0130 & 0.0018 & 0.0076 & 0.0005 & 0.0546 & 0.0030 \\
\hline Modern & 48 & 0.0180 & 0.0021 & 0.0117 & 0.0016 & 0.0063 & 0.0006 & 0.0351 & 0.0019 \\
\hline Total & 97 & 0.0193 & 0.0014 & 0.0124 & 0.0012 & 0.0069 & 0.0004 & 0.0449 & 0.0020 \\
\hline
\end{tabular}

Source: Authors

For testing the relation between employee density and shelf based out-of-stock moderated with retail formats, we conducted hierarchical multiple regression. Therefore, after adding the interaction terms, we compared two regression models (reduced and full).

Hierarchical Multiple Regression

\begin{tabular}{|c|c|c|c|c|c|c|c|c|c|c|}
\hline \multirow{2}{*}{ Model } & \multirow{2}{*}{$\mathbf{R}$} & \multirow{2}{*}{$\mathbf{R}^{2}$} & \multirow{2}{*}{ Adj. $R^{2}$} & \multirow{2}{*}{ Std. E. } & \multicolumn{5}{|c|}{ Change Statistics } & \multirow{2}{*}{ Durbin-Watson } \\
\hline & & & & & $\mathbf{R}^{2}$ & $\mathbf{F}$ & df1 & df2 & Sig. F & \\
\hline $1^{*}$ & 0.193 & 0.037 & 0.006 & 0.0042 & 0.037 & 1.197 & 3 & 93 & 0.315 & \\
\hline $2^{* *}$ & 0.656 & 0.430 & 0.399 & 0.0032 & 0.393 & 31.387 & 2 & 91 & 0.000 & 2.197 \\
\hline
\end{tabular}

Source: Authors

As presented in Table 2, the $\mathrm{R}^{2}$ change was 0,393 which means that the interaction between employee density and retail formats explained an additional 39,3\% of the variance in shelf based out-of-stocks. According to the results of $\mathrm{F}$ test, this change in $\mathrm{R}^{2}$ is significant $(F(2,91)=31,387, p<0,01)$, while at the first model $p$ value is higher than $0,05 \quad(\mathrm{p}=0,315)$. The Durbin-Watson statistics of 2,197 is within the acceptable range of 1,5 to 2,5 , pointing that there is no auto-correlation in a regression analysis. The following table shows regression coefficients for reduced and full model as well.

Reduced and Full Regression Models

Table 3

\begin{tabular}{|c|c|c|c|c|c|c|c|}
\hline Model & Variables & $\begin{array}{c}\text { Unstan } \\
\text { B }\end{array}$ & $\begin{array}{l}\text { oeff. } \\
\text { Std. E. }\end{array}$ & $\begin{array}{c}\text { Stand. Coeff. } \\
\text { Beta }\end{array}$ & $\mathbf{t}$ & Sig. & VIF \\
\hline \multirow{4}{*}{1} & Intercept & 0.007 & 0.001 & & 9.820 & 0.000 & \\
\hline & $E D_{c}$ & -0.026 & 0.026 & -0.128 & -1.028 & 0.307 & 1.490 \\
\hline & $E D_{c}{ }^{2}$ & 0.188 & 0.770 & 0.027 & 0.244 & 0.808 & 1.216 \\
\hline & $C$ & -0.001 & 0.001 & -0.080 & -0.688 & 0.493 & 1.302 \\
\hline \multirow{6}{*}{2} & Intercept & 0.008 & 0.001 & & 13.521 & 0.000 & \\
\hline & $E D_{c}$ & 0.023 & 0.025 & 0.109 & 0.894 & 0.374 & 2.374 \\
\hline & $E D_{c}{ }^{2}$ & 0.059 & 0.664 & 0.009 & 0.089 & 0.929 & 1.499 \\
\hline & $C$ & -0.003 & 0.001 & -0.381 & -3.388 & 0.001 & 2.023 \\
\hline & $E D_{c} \times C$ & -0.266 & 0.045 & -0.660 & -5.854 & 0.000 & 2.031 \\
\hline & $E D_{c}^{2} \times C$ & 15.197 & 2.389 & 0.731 & 6.361 & 0.000 & 2.112 \\
\hline
\end{tabular}

Source: Authors

In both models the coefficient of employee density $\left(E D_{c}\right)$ and its quadratic term $\left(E_{c}{ }^{2}\right)$ had $p$ values higher than 0,05 . However, opposite to the first one, in the second model (full regression model), negative regression coefficient of coded variable had statistically significant ttest $(\mathrm{p}=0,001)$. In full regression model, the coefficients of interaction terms $\left(\mathrm{ED}_{\mathrm{c}} \mathrm{xC}\right.$ and $\left.\mathrm{ED}_{\mathrm{c}}{ }^{2} \mathrm{xC}\right)$ were also statistically significant with $\mathrm{p}<0,01$. In addition, as all VIF values ranged from 1 to 3 , there was no multicollinearity problem.

Bearing in mind these results, as well as the fact that the change in $\mathrm{R}^{2}$ is significantly greater than zero, we can conclude that relationship between employee density and shelf based OOS differs among traditional and modern store formats, which confirms our hypothesis $H_{1}$. Following Cohen et al. (2003), we rearranged equation 3 to show this relation within each format:

Shelf based OOS $_{\text {store }}=\left(b_{0}+b_{3} C\right)+\left(b_{1}+b_{4} C\right) E D_{c}+\left(b_{2}\right.$ $\left.+b_{5} C\right) E D_{c}^{2}$

In equation 4 terms in brackets, $\left(b_{0}+b_{3} C\right),\left(b_{1}+b_{4} C\right)$ and $\left(b_{2}+b_{5} C\right)$ represent intercept, linear slope and quadratic slope, respectively. After substituting the values of the dummy code (C) and unstandardized coefficients (b), we got two simplified equations for traditional and modern formats:

Shelf based $O O S_{\text {store }}=0,008+0,023 E D_{c}+0,059 E D_{c}{ }^{2}$, for traditional format

Shelf based $O O S_{\text {store }}=0,005-0,243 E D_{c}+15,256 E D_{c}^{2}$, for modern format

For both formats quadratic slopes were positive $(0,059$ and 15,256). On the other hand, while simple slope for traditional format group was positive $(0,023)$, for modern format group it was negative $(-0,243)$. In order to test the statistical significances of these slopes, we replaced two continuous predictors $\left(\mathrm{ED}_{\mathrm{c}}\right.$ and $\left.\mathrm{ED}_{\mathrm{c}}{ }^{2}\right)$ with four new variables (Cohen et al., 2003). Thereby, for both traditional and modern formats we have one linear and one quadratic variable, representing group's $\mathrm{ED}_{\mathrm{c}}$ and $\mathrm{ED}_{\mathrm{c}}{ }^{2}$ values respectively, while other group was coded 0 . The reproduced regression model is presented in Table 4. 
Reproduced Regression Model

\begin{tabular}{|c|c|c|c|c|c|c|}
\hline \multirow{2}{*}{ Variables } & \multicolumn{2}{|c|}{ Unstandardized Coeff. } & \multirow{2}{*}{$\frac{\text { Stand. Coeff. }}{\text { Beta }}$} & \multirow{2}{*}{$\mathbf{t}$} & \multirow{2}{*}{ Sig. } & \multirow{2}{*}{ VIF } \\
\hline & B & Std. E. & & & & \\
\hline Intercept & 0.008 & 0.001 & & 13.521 & 0.000 & \\
\hline C & -0.003 & 0.001 & -0.381 & -3.388 & 0.001 & 2.023 \\
\hline$E D_{\text {traditional format }}$ & 0.023 & 0.025 & 0.086 & 0.894 & 0.374 & 1.470 \\
\hline$E D_{\text {traditional format }}^{2}$ & 0.059 & 0.664 & 0.009 & 0.089 & 0.929 & 1.627 \\
\hline ED modern format & -0.243 & 0.038 & -0.604 & -6.452 & 0.000 & 1.400 \\
\hline$E D_{\text {modern format }}^{2}$ & 15.256 & 2.295 & 0.734 & 6.648 & 0.000 & 1.948 \\
\hline
\end{tabular}

Source: Authors

Opposite to traditional, regression slopes (linear and quadratic) are statistically significant $(\mathrm{p}<0,05)$ only for modern format group confirming the existence of quadratic effect of employee density on shelf based out-of-stocks. This supports our hypothesis $\mathrm{H}_{2}$.

\section{Discussion}

Modern retail formats, opposite to traditional, have much wider and deeper product range and assortment, and thus a lot more work for employees. Thereby, in stores with smaller number of employees per square meter of sales room, exhaustion and stress can set in, reducing the efficiency of work (Angerer, 2005). This can cause employees errors, especially in replenishment operations. Also, in larger stores, excessive products are often randomly assigned in backroom areas (Gruen \& Corsten, 2007), which makes more difficult for employees to find them and replenish the shelf. According to several authors (Angerer, 2005; Gruen \& Corsten, 2007; Ton \& Raman, 2010; Eroglu et al., 2011), higher inventory levels may cause problems in in-store operations, which Waller et al. (2010) attributed as "backroom logistics effect". Difficulties and delays in replenishment process, common in stores with larger backrooms and deeper assortments, usually result in higher shelf based OOS levels.

Similar to understaffed, stores with too many employees are also related to higher shelf-based out-ofstocks. In such conditions, problems concerning task coordination (Angerer, 2005) and delegation of obligations and responsibilities may occur and thus cause employees errors and shelf based OOS.

The occurrence of employee mistakes in retail stores can also be influenced by low wages, inadequate trainings and poor motivation (Ton, 2012). Because of the fact that labour is one of the largest cost factors (Trautrims, 2011), retailers are not so willing to invest in it. Retail employees are among the lowest-paid workers. According to Ton (2012, p. 130), poorly paid, poorly trained and poorly motivated employees are less productive and make more errors.

In addition to small wages, demanding work conditions (such as unpredictable work schedules, long and night shifts) can also affect their motivation and job satisfaction (Ton, 2012), which is why it often happens that employees deliberately make mistakes or avoid performing their tasks. These conditions, followed by low level of competencies (due to the lack of the knowledge and adequate training) also influence high level of employee turnover. According to DeHoratius \& Ton (2009) retail stores experience higher rates of employee turnover than other sectors. Besides, a large proportion of part-time workers are found in the retail sector (Giannikis \& Mihail, 2011). Retail store employees (where part-time workers presents high share of labour force) are usually concentrated in the secondary labour market, and in lowlevel jobs where they experience low compensation and inferior employment benefits, low training and promotion opportunities relative to full-time workers, low skill and competency level, low job security and a low level of demarcation between jobs (Walsh, 2007; Giannikis \& Mihail, 2011). According to the results of the research of Zeitinoglu et al. (2004) "job insecurity, short- and splitshifts, unpredictability of hours, low wages and benefits in part-time and casual jobs in retail sector, and the need to juggle multiple jobs to earn a living wage" create stress, absenteeism, high turnover and workplace conflicts in retail trade, which are the most difficult problems in the area of employee and human resource management.

\section{Managerial Implications}

Under the pressure of growing competition to reduce their costs, retailers usually analyze the employee issue through wages and other cost factors. In this way, not only that cost reduction may not be achieved in a long run, but many problems concerning lower efficiency and poorer onshelf availability may occur.

Thereby, when determining the required number of employees, in addition to wages and their participation in sales, managers should consider other criteria as well. They should pay special attention to monitoring the execution of the tasks where employee errors are the most frequent (Ton, 2008). So, one of the criteria used for their optimization can be the percentage of products not returned to the distribution centre. The required number of employees can also be set by the use of computerized scheduling systems, whereby size of the staff is adapted to the estimated total workload (Ton, 2008).

In order to improve on-shelf availability, retailers can invest in employees' quality as well. By implementing various learning and training methods, such "on the job training" (OJT), learning logs, simulation games and short presentations, the employees are enabled to learn and apply their knowledge concerning out-of-stocks (ECR UK, 2007). Through cross-trainings, they can be thought to perform multiple tasks (to manage a particular section, perform inventory checks, order merchandise, replenish products from backrooms etc.), which increases their productivity and allows retailers to move employees from one store to another (Ton, 2012). In addition to training, rewards, training for teamwork, employee empowerment 
and the increase of responsibility have also positive effects on employees' motivation (ECR UK, 2007; Ton, 2012). In the area of compensation, retailers can implement different incentive techniques and "cafeteria" benefits in order to stimulate and motivate employees to make greater efforts on the job. Consequently, the higher degree to which employees' important needs and desired human values are fulfilled by their work, the greater is job satisfaction (Rozkwitalska \& Basinska, 2015), and thus the company's competitiveness and success (Garrido et al., 2005).

In addition to investing in employees, the decrease of their errors and higher efficiency of the in-store processes can also be achieved through the application of contemporary technological and information systems. A special place among them is taken up by the RFID technology, which enables automated backroom-to shelf tracking of products in the store. Implementation of this system can yield many benefits to retailers, i.e. cut costs or increase the level of their services (Condea et al., 2012), even in the case of products cheaper than RFID tags (Piramuthu et al., 2014). In the execution of replenishment operations, employees may benefit greatly from other systems as well, such as smart shelves, pick-to-light (PTL) and pick-to-voice (PTV) systems.

\section{Conclusions}

Being directly related to the level of service, providing an adequate level of on-shelf availability is one of the main tasks of retailers. If they cannot find the desired product on the labelled sale position, the customers will be subjected to the loss of money, time and energy. In addition to these, retailers and manufacturers in out-of-stock situations are also faced with direct losses, expressed through percentage loss of sales. However, what particularly worries both retailers and manufacturers is the negative impact of the OOS problem on customer satisfaction, which can reflect in the long run on their operation through reduced customer and/or brand loyalty.
Several papers and studies confirm that the main causes of stock-outs occur in retail stores. In this regard, the great responsibility for them is borne by the retailers. In this, a significant percentage of stock-outs accounts for shelf based OOS situations, when products are not found on the labelled sale positions despite being actually present in the store. In most cases, this occurs due to deliberate or unintended mistakes made by employees when executing the shelf replenishment processes. Consequently, this depends to a great extent on the number, training, workload, motivation and organization of store employees.

The results of our research have shown that the impact of employee density on shelf based OOS varies among retail formats, confirming the first hypothesis. However, unlike the traditional, these relations are significant only at modern formats. Hereby, both understaffed and overstaffed larger stores are exposed to higher levels of shelf-based OOS, what is in accordance with our second hypothesis. While in the former, employees have more work and may experience more exhaustion and stress, in the latter, problems in the organization of in-store operations, followed by the inadequate delegation of obligations and responsibility may occur. Also, one should not neglect low wages, insufficient training and weak motivation of employees in the retail sector, causing errors in the execution of internal operations in the store, and thus the occurrence of shelf based OOS. Because of this, more attention should be dedicated to store employees in retail sector, with emphasize on both quantitative and qualitative aspects of their managing.

In future research, the presented model may be extended with new variables. The object of analysis may include employee training, their experience, etc. The impact of employee density on stock-outs can be researched from the cost aspect as well, with special reference to their wages. Also, the obtained results can be used as a basis for future qualitative researches with store managers.

\section{References}

Aastrup, J., \& Kotzab, H. (2010). Forty years of out-of-stock research - and shelves are still empty. The International Review of Retail, Distribution and Consumer Research, 20(1), 147-164. http://dx.doi.org/10.1080/0959396090 3498284

Aastrup, J., \& Kotzab, H. (2009). Analyzing out-of-stock in independent grocery stores: an empirical study. International Journal of Retail \& Distribution Management, 37(9), 765-789. http://dx.doi.org/10.1108/09590550910975817

Andersen Consulting. (1996). Where to look for incremental sales gain; the retail problem of out-of-stock. Coca-Cola Retailing Research Council. Available from internet: http://www.ccrrc.org/1996/02/24/where-to-look-forincremental-sales-gains-the-retail-problem-of-out-of-stock-merchandise/.

Anderson, E., Fitzsimons, G., \& Simester, D. (2006). Measuring and mitigating the costs of stockouts. Management Science, 52(11), 1751-1763. http://dx.doi.org/ 10.1287/mnsc.1060.0577

Andreevska, B., Daskalovic, Dj., Dolapchieva, D., \& Vasileva, K. (2014). Southeast Europe's biggest companies. Seenews, All Data Processing Ltd. Available from internet: http://www.top100.seenews.com/wp-content/uploads/ 2014/09/SeeNewsTOP100SEE-2014.pdf.

Angerer, A. (2005). The impact of automatic store replenishment systems on retail. PhD. University of St. Gallen, Graduate School of Business Administration, Economics, Law and Social Sciences.

Blesic, I., Dragin, A., Markovic, J., Cerovic, S., \& Deri, L. (2014). Relationships among shopping quality and corporate social responsibility of shopping centers and consumer satisfaction: case from Novi Sad (Serbia). Amfiteatru Economic, 16(35), 415-429. 
Bouzaabia R., Bouzaabia, O., \& Capatina, A. (2013). Retail logistics service quality: a cross cultural survey on customer perceptions. International Journal of Retail \& Distribution Management, 41(8), 627-647. http://dx.doi.org/10.1108 /IJRDM-02-2012-0012

Cohen, J., Cohen, P., West, S., G. \& Aiken, L., S. (2003). Applied multiple regression/correlation analysis for the behavioural sciences, 3rd ed. New Jersey: Lawrence Erlbaum Associates, Inc.

Condea, C., Thiesse, F., \& Fleisch, E. (2012). RFID-enabled shelf replenishment with backroom monitoring in retail stores. Decision Support Systems, 52(4), 839-849. http://dx.doi.org/10.1016/j.dss.2011.11.018

Corsten, D., \& Gruen, T. (2003). Desperately seeking shelf availability: an exanimation of the extent, the causes, and the efforts to address retail out-of-stock. International Journal of Retail \& Distribution Management, 31(12), $605-617$. http://dx.doi.org/10.1108/09590550310507731

Cottet, P., Lichtle, M., \& Plichon, V. (2006). The role of value in services: a study in a retail environment. Journal of Consumer Marketing, 23(4/5), 219-227. http://dx.doi.org/10.1108/07363760610674347

DeHoratius, N., \& Ton, Z. (2009). The Role of Execution in Managing Product Availability. In Agrawal, N., \& Smith, S. (Ed.), Retail Supply Chain Management (pp. 53-79). New York: Springer.

ECR UK. (2007). Availability 2007. ECR UK. Available from internet: http://www.ecr-all.org/files/Availability.pdf.

ECR AP. (2012). On Shelf Availability in Asia Pacific, Asia Pacific region: Efficient consumer response Asia Pacific. Accenture. Available from internet: http://www.ecr-all.org/upload/blogfiles/0de/APAC\%20ECR\%20OSA\%20Rep ort\%202012.pdf.

Ehrenthal, J. C. F., \& Stolzle, W. (2013). An examination of the causes for retail stockouts. International Journal of Physical Distribution \& Logistics Management, 43(1), 54-69. http://dx.doi.org/10.1108/09600031311293255

Ehrenthal, J., Gruen, T., \& Hofstetter, J. (2014). Value attenuation and retail out-of-stocks, a service-dominant logic perspective. International Journal of Physical Distribution \& Logistics Management, 44(1/2), 39-57. http://dx.doi.org/10.1108/IJPDLM-02-2013-0028

Eroglu, C., Williams, B., \& Waller, M. (2011). Consumer-driven retail operations - the moderating effects of consumer demand and case pack quantity. International Journal of Physical Distribution \& Logistics Management, 41(5), 420 434. http://dx.doi.org/10.1108/09600031111138808

Fairris, D. (2004). Towards a theory of work intensity. Eastern Economic Journal, 30(4), 587-602.

FMI/GMA Trading Partner Alliance. (2014). Solving the out-of-stock problem. FMI/GMA Trading Partner Alliance report. Available from internet: http://www.gmaonline.org/file-manager/15032FMIN_TPA_OutofStock_v41.pdf.

Frazier, P. A., Tix, A. P., \& Barron, K. E. (2004). Testing moderator and mediator effects in counselling psychology research. Journal of Counseling Psychology, 51(1), 115-134. http://dx.doi.org/10.1037/0022-0167.51.1.115

Garrido, M. J., Perez, P., \& Anton, C. (2005). Determinants of sales manager job satisfaction. An analysis of Spanish industrial firms. The International Journal of Human Resource Management, 16(10), 1934-1954. http://dx.doi.org/ 10.1080/09585190500298776

Giannikis, S. K., \& Mihail, D. M. (2011). Modelling job satisfaction in low-level jobs: Differences between full-time and part-time employees in the Greek retail sector. European Management Journal, 29(2), 129-143. http://dx.doi.org/10. 1016/ j.emj.2010.12.002

Grewal, D., Levy, M., \& Kumar, V. (2009). Customer experience management in retailing: an organizing framework. Journal of Retailing, 85(1), 1-14. http://dx.doi.org/10.1016/j.jretai.2009.01.001

Grubor, A., \& Milicevic, N. (2015). The analysis of fmcg product availability in retail stores. Inzinerine EkonomikaEngineering Economics, 26(1), 67-74. http://dx.doi.org/10.5755/j01.ee.26.1.7070

Gruen, T., Corsten, D., \& Bharadwaj, S. (2002). Retail out-of-stocks: a worldwide examination of extent, causes and consumer responses. Grocery Manufacturers of America, Food Marketing Institute. Available from internet: http://itsoutofstock.com/wp-content/uploads/2013/04/GMA_2002_-Worldwide_OOS_Study.pdf

Gruen, T., \& Corsten, D. (2007). A comprehensive guide to retail out-of- stock reduction in the fast-moving consumer goods industry. Grocery Manufacturers Association. Available from internet: http://www.nacds.org/pdfs/ membership/out_of_stock.pdf.

Hausruckinger, G. (2005). Approaches to measuring on-shelf availability at the point of sale. ECR Europe. Available from internet: www.ecr-all.org/files/OSA-Measurement-White-Paper-final_E1.pdf.

Kim, M., \& Lennon, S. (2011). Consumer response to online apparel stockouts. Psychology \& Marketing, 28(2), $115-144$. http://dx.doi.org/10.1002/mar.20383

Levy, M., \& Weitz, B. (2012). Retailing management eight edition. New York: McGraw-Hill.

Lovreta, S., Petkovic, G., \& Koncar, J. (2009). Marketing channels. Belgrade: Faculty of Economics.

McKinnon, A., Mendes, D., \& Nabateh, M. (2007). In-store logistics: an analysis of on-shelf availability and stockout response for three product groups. International Journal of Logistics: Research and Applications, 10(3), $251-268$. http://dx.doi.org/10.1080/13675560701478075 
Papakiriakopoulos, D., \& Doukidis, G. (2011). Classification performance for making decisions about products missing from the shelf. Advances in Decision Sciences, Special Section, 1-13. http://dx.doi.org/10.1155/2011/515978

Piramuthu, S., Wochner, S., \& Grunow, M. (2014). Should retail stores also RFID-tag „,cheap” items? European Journal of Operational Research, 233(1), 281-291. http://dx.doi.org/10.1016/j.ejor.2013.08.051

Progressive Grocer. (1968). The out-of-stock study. Part I. October, 1-16.

Roland Berger Consultants. (2003). ECR - optimal shelf availability increasing shopper satisfaction at the moment of truth. ECR Europe. Available from internet: http://ecr-all.org/bluebooks/bluebook,ECR+Europe/

Rozkwitalska, M., \& Basinska, B. A. (2015). Job satisfaction in the multicultural environment of multinational corporations: Using the positive approach to empower organizational success. Baltic Journal of Management, 10(3), 366-387. http://dx.doi.org/10.1108/BJM-06-2014-0106

Ton, Z., \& Raman, A. (2010). The effect of product variety and inventory levels on retail store sales: a longitudinal study. Production and Operations Management, 19(5), 546-560. http://dx.doi.org/10.1111/j.1937-5956.2010.01120.x

Ton, Z. \& Raman, A. (2006). Cross-sectional analysis of phantom products at retail stores. Working paper. Boston: Harvard Business School.

Ton, Z. (2008). The hidden risk in cutting retail payroll. Harvard Business Review, 86(3), 22-22.

Ton, Z. (2012). Why "good jobs" are good 4 retailers. Harvard Business Review, 90(1/2), 124-131.

Trautrims, A., Grant, D. B, Fernie, J., \& Harrison, T. (2009). Optimizing on-shelf availability for customer service and profit. Journal of Business Logistics, 30(2), 231-247. http://dx.doi.org/10.1002/j.2158-1592.2009.tb00122.x

Trautrims, A. (2011). Management of in-store replenishment systems: an exploratory study of European retailers. PhD, The University of Hull.

Waller, M. A., Williams, B. D., Tangari, A. H., \& Burton, S. (2010). Marketing at the retail shelf: exploring moderating effects of logistics on sku market share. Journal of the Academy of Marketing Science, 38(1), $105-117$. http://dx.doi.org/10.1007/s11747-009-0146-0

Walsh, J. (2007). Experiencing part-time work: temporal tensions, social relations and the work-family interface. British Journal of Industrial Relations, 45(1), 155-177. http://dx.doi.org/10.1111/j.1467-8543.2007.00606.x

Wlodarczyk, K. (2013). Behavior displayed by Polish consumers in their leisure time in the light of recent research. Transformations in Business \& Economics, 12(29B), 538-553.

West, S. G., Aiken, L. S., \& Krull, J. L. (1996). Experimental personality designs: Analyzing categorical by continuous variable interactions. Journal of Personality, 64(1), 1-48. http://dx.doi.org/10.1111/j.1467-6494.1996.tb00813.x

Whisman, M. A., \& McClelland, G. H. (2005). Designing, testing, and interpreting interactions and moderator effects in family research. Journal of Family Psychology, 19(1), 111-120. http://dx.doi.org/10.1037/0893-3200.19.1.111

Zeytinoglu, I. U., Lillevik, W., Seaton, M. B., \& Moruz, J. (2004). Part-time and casual work in retail trade: stress and other factors affecting the workplace. Relations industrielles/Industrial Relations, 59(3), 516-544. http://dx.doi.org/10.7202/010923ar

The article has been reviewed.

Received in September, 2016; accepted in October, 2017. 